\title{
Rapid lectin-based staining procedure for the detection of the myxosporean causing proliferative kidney disease in salmonid fish
}

\author{
R. P. Hedrick ${ }^{1, *}$, M. Marin ${ }^{2}$, M. Castagnaro ${ }^{2}$, D. Monge ${ }^{3}$, P. de Kinkelin ${ }^{3}$ \\ ${ }^{1}$ Department of Medicine, School of Veterinary Medicine, University of California, Davis, California 95616, USA \\ ${ }^{2}$ Dipartimento di Patologia Animale, Via Nizza 52, I-10126, Torino, Italy \\ ${ }^{3}$ Unité de Virologie et d'Immunologie Moléculaires, INRA, Jouy-en-Josas, France
}

\begin{abstract}
Lectins are proteins found initially in plants but now known from viruses, protozoans and higher animals which recognize specific glycoconjugates on cell surfaces. A rapid staining procedure using the lectin GS-1 from Griffonia simplicifolia was developed for the detection of PKX, the myxosporean causing proliferative kidney disease (PKD) in salmonid fish. A single developmental (extrasporogonic) stage of PKX could be recognized in fixed and stained kidney imprints from infected salmonids. The staining procedure involves an initial incubation of a fixed kidney imprint with 5 to $10 \mu \mathrm{g} \mathrm{ml}^{-1}$ of biotinylated GS-1 in phosphate buffered saline (PBS). Bound lectin is visualized by adding avidin conjugated with fluorescein $\left(10\right.$ to $\left.30 \mu \mathrm{g} \mathrm{ml}^{-1}\right)$. The lectin-based stain removes much of the subjective evaluation required by standard Giemsa staining and fresh mount observations and is much more rapid $(2 \mathrm{~h})$ than standard histological procedures used for confirmatory diagnoses of PKD. The lectin stain performed equally well with PKX originating from 3 species of salmonids from France, USA, and British Columbia, Canada. The sensitivity of the procedure was not compared to histological evaluations but the lectin stain was able to detect parasites in very early stages of PKD, well before the onset of renal swelling. Although additional myxosporeans need to be tested, there was no evidence for binding of the lectin to a renal Sphaerospora sp., that does not cause PKD, found in brown trout (Salmo trutta).
\end{abstract}

\section{INTRODUCTION}

Lectins are proteins first described from plants that possess the unique ability to recognize certain glycoconjugates (Goldstein \& Hayes 1978). The specificity of lectins for carbohydrate moieties depends not only on the position of monosaccharides and number of branch points, but also on their anomeric form (types of linkages between residues). These features of lectins give them the ability to distinguish with high fidelity a wide range of carbohydrate structures on the surface of cells (McCoy 1987). Although the role of lectins is not completely understood, their importance in cell recognition as related to mitogenesis, agglutination and direction of cell cytotoxicity has been established (Sharon \& Lis 1989). As a result of their unique binding capabilities, lectins have been used extensively for the recognition of cell populations including human blood cell types (Judd 1980).

Proliferative kidney disease ( $\mathrm{PKD}$ ) is a serious sys-

\footnotetext{
- Addressee for correspondence
}

temic protozoal infection experienced by several species of salmonid fish both in Europe and North America (Ferguson \& Needham 1978, Clifton-Hadley et al. 1984, Hedrick et al. 1986). The disease is caused by a currently unclassified myxosporean, PKX (Kent \& Hedrick 1985, 1986, Odening et al. 1988, Clifton-Hadley \& Feist 1989). Developmental and sporogonic stages of PKX most closely resemble species of the genus Sphaerospora (Hedrick et al. 1988, Oedining et al. 1988, Clifton-Hadley \& Feist 1989), a group of myxosporeans prevalent in the blood and kidney of fresh water and marine fishes (Arthur \& Lom 1985). During episodes of clinical PKD, detection of PKX is relatively simple. Direct observations of fresh kidney mounts (Hedrick et al. 1986) or after adding methylene blue (Klontz \& Chacko 1983) suffice to reveal the typical developmental or extrasporogonic stage of the parasite (PKX) needed for a presumptive diagnosis of PKD. Kidney impressions first fixed with methanol and then stained with Giemsa are also often employed for rapid presumptive diagnoses (Clifton-Hadley et al. 1983). A 
confirmatory diagnosis using hematoxylin and eosin stained tissue sections that show both PKX and the accompanying inflammatory response are often employed (Ferguson \& Needham 1978). While generally effective, none of these conventional methods are based on a specific binding or recognition of PKX but instead rely on morphological or subtle staining differentiations of the parasite. In addition, difficulties can be encountered when conventional stains are applied to thick impressions or smears or when parasite numbers are low. Furthermore, during phases of PKD with little or no inflammatory responses very early stages or late sporogonic forms may be difficult to recognize.

Only recently have serological approaches for detection of PKX been developed. These include detection of PKX using anti-PKX antibodies found in trout serum (Hedrick et al. 1992) and direct detection of PKX using a monoclonal antibody (S. Adams pers. comm.). In efforts to develop a rapid test for recognizing $\mathrm{PKX}$, we have expanded on initial observations by Castagnaro et al. (1991) which showed that the GS-1 lectin from Griffonia simplicifolia, which recognizes methyl- $\alpha$-Dgalactopyranosides, binds glycoconjugates present on the PKX myxosporean. We describe in this paper a rapid, 3-step fluorescence test using fixed kidney imprints which provides an alternative to conventional staining procedures for detection of PKX in salmonid fish.

\section{MATERIALS AND METHODS}

Tissue imprints. Rainbow trout Oncorhynchus mykiss, chinook $O$. tshawytscha and coho $O$. kisutch salmon with proliferative kidney disease were obtained from France, USA (California) and Canada (British Columbia), respectively. Kidney and spleen impressions were made from rainbow trout at various stages of the disease following natural exposures (Chilmonczyk et al. 1989) ranging from 2 to $12 \mathrm{wk}$ post exposure to the parasite. Kidney impressions were made from chinook and coho with clinical signs of PKD from culture facilities where active epizootics were underway Fish were anesthetized, bled, and a portion of the kidney removed, blotted on tissue and then used to make imprints on multiwell glass slides (ICN Biomedical Inc., Horsham, Pennsylvania, USA). After air drying for 30 min, imprints were fixed in acetone-ethanol $(60: 40)$ at $-20{ }^{\circ} \mathrm{C}$ for $10 \mathrm{~min}$. Slides were air dried and used immediately or stored at $-70^{\circ} \mathrm{C}$ under desiccated conditions. Kidney tissues from brown trout Salmo trutta from northern Italy with a Sphaerospora sp., which does not induce a proliferative condition (G. Bovo pers. comm.), were prepared in the same manner as those from fish with PKD. Multiwell slides were prepared so that each slide contained tissue imprints from both infected and uninfected fish. The latter served as negative controls for each staining procedure.

Staining Procedure. The biotinylated GS-1 lectin from Griffonia simplicifolia (L-3759, Sigma, St. Louis, Missouri, USA) was suspended in $0.01 \mathrm{M}$ phosphate buffer pH 6.8 to provide dilutions of $25,10,5,1$ and $0.5 \mathrm{\mu g} \mathrm{ml} \mathrm{m}^{-1}$ Aliquots of $50 \mu \mathrm{l}$ were placed on replicate kidney impressions from fish with PKX and an uninfected control fish. The slides were incubated in a moist chamber for 1 to $2 \mathrm{~h}$ at $25^{\circ} \mathrm{C}$. The slides were then rinsed 3 times in PBS and $50 \mu$ of fluorescein avidin D (A-2001, Vector Laboratories, Inc., Burlingame, California, USA), diluted to provide 10 or $30 \mu \mathrm{g} \mathrm{ml}^{-1}$ suspensions in PBS, was added to replicate impressions. The slides were again incubated in a moist chamber at $25^{\circ} \mathrm{C}$ for $30 \mathrm{~min}$. The slides were rinsed a final 3 times, carefully blotted to near dry and mounted with a coverslip using a drop of a mixture containing 1 part $0.1 \mathrm{M} \mathrm{N}$-2-hydroxy-ethylpiperazine- $\mathrm{N}^{\prime}$-2ethanesulfonic acid (HEPES) pH 8.0 and 9 parts glycerol. The specimens were observed under a photomicroscope equipped with a UV light source and excitation and barrier filters for fluorescein.

\section{RESULTS AND DISCUSSION}

Initial range finding studies were conducted with rainbow trout with clinical signs of PKD and numerous typical extrasporogonic forms of PKX. These studies determined that optimal parasite staining was achieved at concentrations of the biotinylated GS-1 between 5 to $10 \mu \mathrm{g} \mathrm{ml}^{-1}$ with either 10 or $30 \mu \mathrm{g} \mathrm{ml}^{-1}$ of avidin fluorescein. Positive staining with concentrations as low as $0.5 \mu \mathrm{g} \mathrm{m} \mathrm{m}^{-1}$ were evident but these were weaker than at 5 to $10 \mu \mathrm{g} \mathrm{ml}^{-1}$. Both concentrations of avidin fluorescein tested were found to be satisfactory. A brilliant granular surface pattern of fluorescence was detected with PKX cells (Fig, 1). The granular appearance of PKX resulted from a regular distribution on the cell plasmalemma of brightly stained circular to elliptical forms with a diameter of approximately 0.2 to $0.5 \mu \mathrm{m}$. These surface structures were also observed free from the parasite, presumably arising from a physical disruption of the cells during imprint preparation. The importance of these surface glycoconjugates on the parasite is unknown but they were recognized by trout anti-PKX antibodies from fish recovering from $\mathrm{PKD}$ as seen in indirect immunofluorescence tests using rhodamine labeled mouse anti-trout Ig in combination with the GS-1/avidin fluorescein procedure (Hedrick et al. 1992).

Binding of GS-1 to internal daughter cells (secondary or tertiary cells) of PKX in the kidney imprints was observed (Fig. 1) but these cells were weakly stained 
Fig. 1. Developmental stages of the PKX myxosporean in fixed kidney imprints stained with biotinylated lectin GS-1 and avidin fluorescein. Several extrasporogonic PKX stages. Nuclei of primary and daughter cells are devoid of stain. Bar $=20 \mu \mathrm{m}$

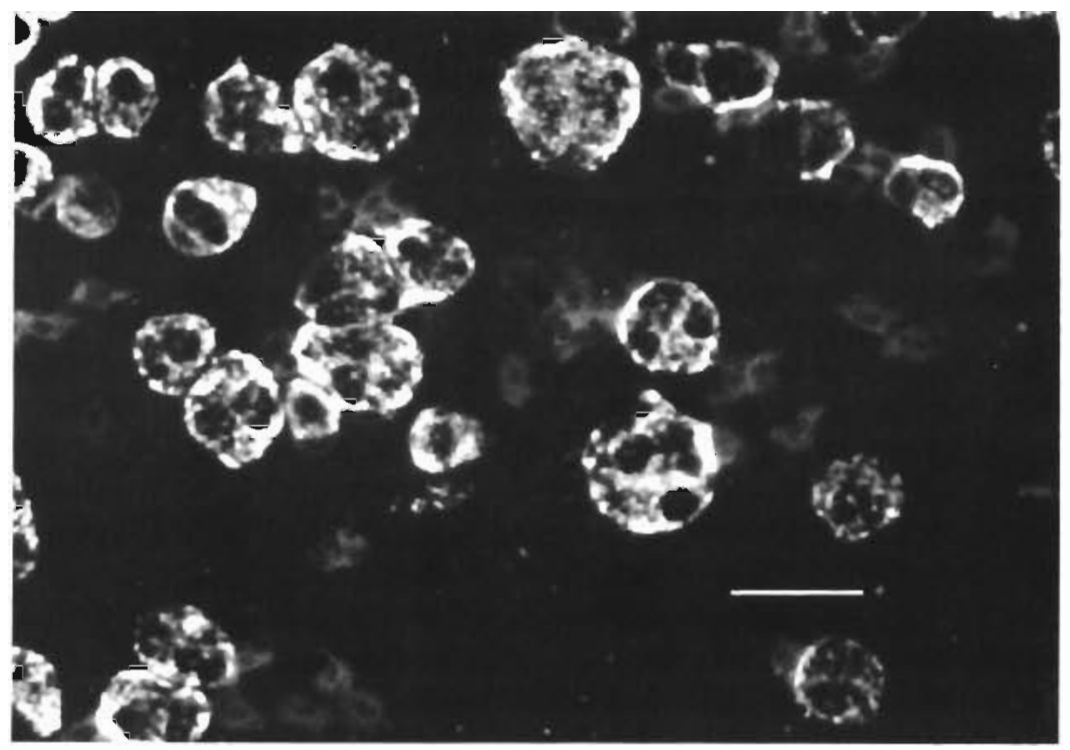

The utility of the lectin-based stain is apparently not

(fewer granules) in comparison to primary cells. However, secondary cells emerging from primary cells by budding or plasmotomy as part of their vegetative developmental cycle (Kent \& Hedrick 1985, 1986) quickly acquired the more intense staining pattern seen with primary cells. The nuclei of primary and daughter cells were left unstained (Fig. 1). Although cytoplasmic staining was evident, the major location for binding of GS-1 to PKX seems to be the cell membrane as observed in fixed preparations and when the staining procedure is applied to living PKX (unpubl.). The reaction of the lectin with sporogonic stages in the lumina of the kidney tubules was not observed because these stages are often obscured in tissue imprints. However, Castagnaro et al. (1991) showed that sporogonic stages as well as the apical border of the tubule epithelium bind GS-1 in histological sections stained with immunoperoxidase. Storage of fixed but unstained impression smears at $4{ }^{\circ} \mathrm{C}$ was found to be adequate for short-term purposes (up to $2 \mathrm{mo}$ ) but staining activity steadily diminished on slides examined after longer storage periods. Better preservation for lectin binding was obtained when slides were stored at $-70{ }^{\circ} \mathrm{C}$ under desiccated conditions.

A comparison of the lectin-based procedure to Giemsa stained imprints or stained tissues sections was not part of the present study. However, the potential utility of the test for screening populations of fish, particularly during less active stages of the disease (no gross or microscopic signs of the inflammation), is demonstrated by the ability to detect a single PKX in an imprint. As opposed to conventionally stained imprints, thickness of the preparation does not influence the quality of the lectin-based stain nor are subjective judgements on parasite identity required. limited to a single strain or variant of PKX as parasites from 3 species of fish from 3 different geographic areas were equally stained (not shown). While this does not prove that all PKX are identical, it does indicate that major glycoconjugates present on the cell surface of these parasites have been conserved as the parasite evolved in different geographic regions. This may suggest an important role for these glycoconjugates in the development of the parasite and the strong immune response elicited in the salmonid host.

The specificity of the lectin-based detection procedure for PKX needs further testing, but at least one additional renal myxosporean found in trout was not recognized by GS-1. Trophozoites of the Sphaerospora $\mathrm{sp}$. from brown trout which do not elicit an inflammatory condition were not stained with the GS-1. Additional species of renal myxosporeans found in salmonids should be tested; these include Ceratomyxa shasta, Myxidium spp., Chloromyxum spp. and Parvicapsula $\mathrm{sp}$.

The speed of the test and the removal of the subjectivity in interpreting results makes the lectin-based stain an attractive alternative to fresh mounts and traditional stains on tissue imprints or sections. The reagents for the test are commercially available and can be utilized by any laboratory with a microscope equipped for fluorescence.

Studies examining the progressive development of PKD from initial natural exposures until resolution of clinical signs and formation of later sporogonic stages are underway using this new staining procedure. The functional role of the glycoconjugates on PKX recognized by GS-1, particularly with respect to interactions with macrophages, is also under investigation. 
Acknowledgements. This work was supported in part by Sport Fish Restoration Act Funds administered by the California Department of Fish and Game and by INRA, Jouy-en-Josas, France. We thank Dr Michael L. Kent for providing fixed kidney impressions from coho salmon used in this study. Ms. M. Marin was supported by a fellowship from the Ministerio de Educacion y Ciencia of Spain.

\section{LITERATURE CITED}

Arthur, J. R., Lom, J. (1985). Sphaerospora araii n sp. (Myxosporea: Sphaerosporidae) from the kidney of a longnose skate (Raja rhina Jordan and Gilbert) from the Pacific Ocean off Canada. Can. J. Zool. 63: 2902-2906

Castagnaro, M., Marin, M., Ghittino, C., Hedrick, R. P. (1991). Lectin histochemistry and ultrastructure of the rainbow trout Oncorhynchus mykiss kidneys affected by proliferative kidney disease. Dis. aquat. Org. 10: 173-183

Chilmonczyk, S., Thomas, P., de Kinkelin, P. (1989). Occurrence of proliferative kidney disease in an indoor recirculation unit and indirect experimental contamination of the rainbow trout. Bull. Eur. Ass. Fish Pathol. 9: 38-41

Clifton-Hadley, R. S., Bucke, D., Richards, R. H. (1984). Proliferative kidney disease of salmonid fish: a review. J. Fish Dis. 7: 363-377

Clifton-Hadley, R. S., Feist, S. W (1989). Proliferative kidney disease in brown trout Salmo trutta: further evidence of a myxosporean aetiology. Dis. aquat. Org. 6: 99-103

Clifton-Hadley, R. S., Richards, R. H., Bucke, D. (1983) Method for the rapid diagnosis of proliferative kidney disease in salmonids. Vet. Rec. 112: 609

Ferguson, H. W., Needham, E. A. (1978). Proliferative kidney disease in rainbow trout, Salmo gairdneri Richardson. J. Fish Dis. 1. 91-108

Responsible Subject Editor: W. Körting, Hannover, Germany
Goldstein, I. J., Hayes, C. E. (1978). The lectins: the carbohydrate binding proteins of plants and animals. Adv Carbohyd. Chem. Biochem. 35: 127-340

Hedrick, R. P., Kent, M. L., Smith, C. E. (1986). Proliferative kidney disease of salmonid fishes. U.S. Dept. of Interior, Fish and Wildlife Service, Fish Dis. Leaflet 74: 1-9

Hedrick, R. P., Kent, M. L., Toth, R. J., Morrison, J. K. (1988). Fish infected with Sphaerospora spp. Thélohan (Myxosporea) from waters enzootic for proliferative kidney disease of salmonids. J. Protozool. 35: 13-18

Hedrick, R. P., Monge, D., Kazanji, M., Pery, P., Marin, M., de Kinkelin P. (1992). Recent developments with proliferative kidney disease. Proc. OJI Int. Symp. Salmonid Diseases. Sapporo, Japan, Oct. 22-24, 1991 (in press)

Judd, W. J. (1980). The role of lectins in blood group serology. CRC Critical Rev. Clin. Lab. Sci. 1: 171-214

Kent, M. L., Hedrick, R. P. (1985). PKX, the causative agent of proliferative kidney disease (PKD) in Pacific salmonid fishes and its affinities with the Myxozoa. J. Protozool. 32: $254-260$

Kent, M. L., Hedrick, R. P. (1986). Development of the PKX myxosporean in rainbow trout Salmo gairdneri. Dis. aquat. Org. 1: 169-182

Klontz, G. W., Chacko, A. J. (1983). Methods to detect the organism causing proliferative kidney disease in salmonids. Bull. Eur Ass. Fish Pathol. 3: 33-36

McCoy, J. P. Jr (1987). The application of lectins to the characterization and isolation of mammalian cell populations. Cancer Metastasis Rev. 6: 595-613

Odening, Von K., Walter, G., Bockhardt, I. (1988). Koinzidentes Auftreten von PKX und Sphaerospora sp. (Myxosporidia) in Beständen von Salmo gairdneri (Osteichthyes). Angew. Parasit 29: 137-148

Sharon, N., Lis, H. (1989). Lectins as cell recognition molecules. Science 246: 227-234

Manuscript first received: January 15, 1992

Revised version accepted: March 12, 1992 